\title{
Unsur Sains dan Sastera dalam novel remaja terpilih
}

\author{
Science and Literature elements in tennagers selected novels \\ Rosnani Md Zain \\ nanieyzain@gmail.com \\ Nik Rafidah Nik Muhamad Affendi \\ nrafidah@upm.edu.my \\ Universiti Putra Malaysia, Serdang, Selangor, Malaysia
}

DOI: https://doi.org/10.37134/pendeta.vol10.12.2019

\begin{abstract}
ABSTRAK
Kertas kerja ini membicarakan unsur sains dan sastera yang terdapat dalam novel remaja terpilih. Kajian yang dilakukan ini bertitik tolak daripada pengamatan pengkaji berdasarkan pandangan sarjana sastera yang mengatakan novel-novel remaja berunsur sains sering dianggap tidak mengetengahkan fakta sains dan mengabaikan nilai sastera seperti yang digambarkan melalui dialog, watak-watak dan peristiwa dalam novel tersebut. Kajian ini akan mengklasifikasi, menganalisis dan merumus unsur sains dan sastera yang diungkapkan oleh pengarang dalam setiap karya yang dihasilkan. Dalam kajian ini, kaedah yang digunakan ialah kualitatif iaitu, kepustakaan, analisis teks dan penerapan teori Sistem Pemikiran Bersepadu (SPB4K). Berdasarkan kajian yang dilakukan, pengkaji mendapati bahawa unsur sains antaranya sains gunaan dan sains zoologi manakala unsur sastera seperti nilai-nilai murni, pemikiran, emosi dan gaya bahasa amat relevan dengan empat prinsip yang terdapat dalam teori Sistem Pemikiran Bersepadu (SPB4K) iaitu Pemikiran Kerohanian, Pemikiran Kebitaraan, Pemikiran Kesaintifikan dan Pemikiran Kekreatifan.
\end{abstract}

Kata Kunci: unsur sains; sastera; SPB4K; novel; remaja.

\section{ABSTRACT}

This paper discusses the science and literature elements found in selected adolescent novels. This study is based on the findings of the scholarly literature based on the view of literary scholars who say that science-based adolescents' novels are often overlooked in science and ignore literary values as illustrated through dialogue, characters and events in the novel. This study will classify, analyze and summarize the science and literature elements revealed by the authors in each work produced. In this study, the methods used are qualitative, library, text analysis and application of Teori Sistem Pemikiran Bersepadu (SPB4K. Based on the research conducted, the researcher found that the elements of science include applied science and zoology while literary elements such as pure values, thinking, emotional and language style are very relevant to the four principles in the Teori Sistem Pemikiran Bersepadu (SPB4K), Pemikiran Kerohanian, Pemikiran Kebitaraan, Pemikiran Kesaintifikan dan Pemikiran Kekreatifan.

Keywords: science; literature; SPB4K; novel; adolescent.

\section{PENGENALAN}

Sejarah perkembangan novel remaja di Malaysia bermula awal dekad 1950-an apabila Pejabat Karang Mengarang menganjurkan siri peraduan mengarang pada tahun 1951 bagi mendapatkan karya yang sesuai untuk bacaan remaja. Hasil daripada peraduan itu lahirlah novel Cincin Rahsia karya Amir Hamzah yang 
dinobatkan sebagai pemenang tempat pertama. Novel ini berkisar mengenai dunia detektif yang diadun dengan unsur saspens dan ketegangan yang cukup mendebarkan sehingga dapat menarik perhatian pembaca remaja. Novel Cincin Rahsia menjadi penanda aras bagi perkembangan novel-novel remaja sehingga mutakhir ini.

Pada peringkat awal, novel remaja sering dikaitkan dengan tema percintaan, kekeluargaan, sejarah, adventure dan sebagainya. Perkembangan semasa telah mengubah hala tuju penulis kini yang mula berani menyisipkan pengalaman, pengetahuan dan penyelidikan dalam pelbagai ilmu termasuk bidang sains, menjadikan adunan karya lebih sarat sifatnya serta menggugah keupayaan penulis itu sendiri. Antara penulis yang sering dikaitkan dengan novel remaja berunsur sains pada dekad 1970-an sehingga 1990-an seperti Othman Puteh, Ajikik, Rubaidin Siwar, Salleh Hamzah, Hizairi Othman dan sebagainya. Menjelang abad ke-21, penulis alaf baharu yang prolifik dalam menghasilkan novel remaja berunsur sains antaranya Nisah Haron, Ahmad Patria Abdullah, Faisal Tehrani, Sri Rahayu Mohd Yusop, Dayang Noor, Ruzaini Yahya dan sebagainya.

Istilah novel remaja pula merujuk kepada gabungan antara dua unsur "novel" dan "remaja" yang menjadikan seni sastera itu membentuk identitinya tersendiri dan berada di dalam kelompoknya sendiri yang tidak boleh disamakan dengan sastera umum atau sastera kanak-kanak (Nor Raudhah Hj. Siren, 2006). Selain itu, Shahnon Ahmad dalam Jumali Selamat (2012) menyatakan novel remaja merupakan karya yang berkisar kepada keperihalan remaja. Sahlan Mohd. Saman (1989) menjelaskan pengertian novel remaja adalah karya sastera yang dihasilkan untuk bacaan remaja. Oleh itu, penciptaan novel remaja wajar memenuhi kehendak khalayak sasarannya supaya sesuai dengan perkembangan jasmani, emosi, rohani dan intelek remaja. Novel sebagai bahan perantara yang dapat memberi nilai ilmu dan sebagai peranti pemikiran penulis yang dapat dihayati sebagai bahan autentik yang sesuai untuk perkembangan remaja.Penelitian bahan yang efektif dapat memupuk generasi awal dari sudut pengayaan pengetahuan, ketinggian berfikir dan memiliki etika dan kerohanian yang unggul sesuai dengan hasrat kurikulum di Malaysia (Anida et. al, 2019).

Dalam hal ini konsep novel remaja perlu memenuhi lima ciri yang utama, iaitu usia remaja, penerapan nilai-nilai murni, penerapan unsur ilmu bantu dan aspirasi dalam karya remaja. Menurut Abdul Ahmad (1991), penerapan unsur ilmu dalam novel remaja perlu dilihat dari dua sudut. iaitu penulis perlu mengetahui serba sedikit mengenai psikologi remaja dan mengenai ilmu yang bersesuaian dengan pengetahuan dan kehendak remaja. Unsur-unsur ilmu yang dikehendaki dalam novel remaja ialah faktafakta yang merangkumi pelbagai disiplin ilmu seperti undang-undang, sains dan teknologi, ekonomi, pendidikan dan sebagainya. Sehubungan dengan itu, penerapan ilmu bantu seperti ilmu sains amatlah dituntut dalam penghasilan novel remaja.

Menurut Esa Khalid (2008), sains didefinisikan sebagai ilmu yang didapati melalui metodologi saintifik. Dalam konteks sains moden, metodologi tersebut terdiri daripada kaedah empirikal dan matematik sahaja. Walaupun sebenarnya dalam konteks sains moden, metodologi saintifik bukanlah bersifat monolik terutamanya pada peringkat amalan praktis, bahkan hakikat ini terserlah dalam sejarah sains. Kamus Oxford Edisi Kelima (2011) pula mentakrifkan sains sebagai satu cabang pengetahuan yang tersusun diperolehi melalui pemerhatian dan pengujian tentang alam semula jadi.Takrif sains yang biasa didukung oleh kebanyakan sarjana dapat dinyatakan sebagai analisis fenomena (alam tabii) secara sistematik dan objektif dengan kaedah khusus yang diperantikan bagi mewujudkan penumpukan pengetahuan yang boleh dipercayai. Hal ini bermaksud sains ialah ilmu pengetahuan yang teratur dan boleh diuji kebenarannya.

Seterusnya, Seth Sulaiman (2000) menyatakan sains merupakan disiplin ilmu yang menerangkan banyak perkara. Ia adalah hasil penyelidikan yang mempunyai kaedah tertentu, satu pengetahuan tersusun, satu alat menyelesaikan masalah, satu institusi sosial, memerlukan sumber bahan, satu sumber kebudayaan yang perlu diurus dan merupakan satu faktor utama dalam pembinaan sesebuah masyarakat. Berdasarkan penelitian tersebut, sains merupakan pengetahuan yang berpaksikan bagaimana manusia mampu untuk mencerap dan memerhati alam tabii yang mengikut fitrahnya. Hasil pencerapan secara sistematik ini kemudiannya dihujahkan dan dianalisis secara mantik dan objektif, dilakukan eksperimen, dan perbandingan dengan andaian teori. Pengetahuan itu terus dipupuk dan dikembangkan untuk 
menambahkan khazanah pengetahuan sains itu sendiri. Seterusnya sains sinonim dengan ketepatan, kejituan dan pembuktian. Prinsip sains berteraskan hipotesis, menaakul secara inferens melalui eksperimen yang dapat direplikasi, data yang dianalisis dan dirujuk silang dengan penemuan yang sedia ada sebelum disahkan kesimpulannya. Kesimpulan sains tentang suatu perkara hanya tunggal dan diterima sebagai benar walau dimana sekalipun fenomena yang dikaji itu berlaku (Rebecca Ilham, 2012).

Seth Sulaiman menambah lagi, bidang sains terbahagi kepada tiga jenis, iaitu pertama sains tulen (tabii) iaitu disiplin ilmu yang menyentuh persekitaran semulajadi manusia itu tinggal. Bidang sains tulen seperti kimia, botani dan fizik. Kedua ialah sains gunaan yang terdiri daripada bidang-bidang kejuruteraan, perubatan dan seni bina. Bidang ini memberikan penekanan terhadap aspek kegunaan hasil-hasil yang didapati daripada sesuatu kajian di dalam sains tabii atau sains kemanusiaan. Sains sosial pula melibatkan pengetahuan manusia yang menyentuh setiap aspek kehidupan kelompok-kelompok manusia di atas muka bumi ini (Bidang ini terdiri daripada sosiologi, antropologi, sains politik, sejarah dan psikologi.

Sementara itu, sastera merupakan manifestasi kesenian yang disampaikan menerusi media bahasa yang kreatif lagi indah, melaluinya khalayak dapat menikmati kehalusan dan keindahannya (Khatijah Abdul Hamid, 1987). Kesusasteraan juga merupakan ekspresi atau pernyataan sebahagian daripada kebudayaan sesuatu bangsa. Dalam hal ini, Mohd. Taib Osman (1989) mengatakan bahawa menerusi karya sebenarnya penulis menyatakan system of ideas atau world view dan system of values yang mempunyai nilai estetikanya yang tersendiri. Dalam pembinaan sesebuah karya sastera, beberapa unsur penting yang perlu ada, antaranya ialah unsur intelek, emosi, imaginasi dan teknik. Menurut Hashim Awang (1998), kesusasteraan itu dicipta untuk mengemukakan sesuatu pemikiran atau falsafah yang bernilai dan bermakna untuk dijadikan sebagai pengajaran atau panduan hidup kepada pembaca. Ini termasuklah pengalaman pengarang yang dirasakan amat baik untuk diketengahkan dalam sesebuah karya sastera yang mungkin terdiri daripada berbagai-bagai persoalan seperti moral, ekonomi, politik, budaya mahupun agama. Kesusasteraan juga tidak tercipta semata-mata untuk menghiburkan tetapi yang lebih penting ialah untuk menggarapkan pemikiran dan pengetahuan yang berguna kepada pembaca dan masyarakat.

Kajian yang dilakukan ini berdasarkan kepada dua buah novel remaja, iaitu Tawanan Komander Caucasus (2010) karya Ruzaini Yahya dan Di Sebalik Dinara (2012) karya Dayang Noor. Tawanan Komander Caucasus mengisahkan sekumpulan remaja yang ditawan oleh tentera kumbang Komander Caucasus. Farhani dan Kim Yang telah dikurung di dalam sebuah tabung uji bersaiz besar di sebuah makmal rahsia Komander Caucasus yang akan menjadikannya sebagai bahan uji kaji untuk mencapai impian Komander Caucasus menakluki dunia dan menguasai manusia.

Novel Di Sebalik Dinara pula mengisahkan watak Farisha yang menjadi mangsa ayah kandungnya sendiri iaitu Karl. Karl merupakan pencipta teknologi yang terlalu taaksub sehingga sanggup mengorbankan nilai-nilai kemanusiaan asalkan hajat dan cita-citanya tercapai.

\section{PERMASALAHAN KAJIAN}

Fenomena kewujudan novel berunsur sains dalam kesusasteraan di tanah air telah mencetuskan reaksi negatif daripada penulis, pembaca dan pengkritik sastera. Pada dasarnya, sains dan sastera merupakan dua cabang ilmu yang dianggap tidak mempunyai titik temu. Maka, daripada persepsi inilah timbul tanggapan negatif sesetengah pihak apabila novel remaja berunsur sains mula diperkenalkan pada tahun 1970-an dalam genre kesusasteraan Melayu moden. Antaranya, Othman Puteh (1989) menyatakan wujud tanggapan negatif sesetengah masyarakat atau pembaca yang menganggap novel berunsur sains bukanlah satu genre sastera yang serius dan tidak mengandungi nilai estetik. Dengan kata lain, novel berunsur sains hanyalah sebuah genre khayalan semata-mata dan tidak memberikan faedah kepada pembaca. Daripada pandangan tersebut dapat dirumuskan novel berunsur sains tidak mempunyai nilai sastera dan dihasilkan tanpa pengetahuan sains.

Kemudian, Hizairi Othman (1998) juga mengatakan wujudnya pandangan negatif penulis dan pembaca yang menganggap novel berunsur sains tidak berjejak di bumi nyata, penuh angan-angan dan 
tidak mempunyai ilmu. Di sebabkan persepsi negatif inilah novel remaja berunsur sains kurang digemari oleh penulis kerana sering dilabel sebagai suka berkhayal dan kurang matang. Ini jelas menggambarkan bahawa tanggapan masyarakat terhadap penghasilan novel remaja berunsur sains tidak bersandarkan kepada fakta sains dan hanya rekaan penulis semata-mata.

Selanjutnya, Ahmad Patria Abdullah dalam artikel Tunas Cipta, Mac 2009 yang berjudul "Penulis Muda dalam Karya-Karya Fantasi dan Futuristik" menyatakan bahawa novel berunsur sains sering kali dianggap sebagai sesuatu yang tidak signifikan, tidak mempunyai nilai estetika, tidak menuntut kemahiran berkarya yang tinggi dan tidak relevan diangkat sebagai salah satu cabang genre penulisan kesusasteraan Melayu. Kenyataan ini menjelaskan bahawa masyarakat beranggapan karya berunsur sains mengabaikan nilai-nilai sastera dan tidak mengetengahkan fakta sains yang tepat. Menjelaskan hal ini, Ahmad Patria menolak dakwaan tersebut dan menegaskan penulisan karya berunsur sains memerlukan pengetahuan sains yang mantap dan ianya sering menjadi asas dalam penghasilan karya berunsur sains.

Berdasarkan perbincangan di atas, maka jelaslah bahawa novel remaja berunsur sains sering dianggap tidak mempunyai nilai sastera dan tidak mengetengahkan fakta sains seperti yang digambarkan melalui dialog, watak-watak dan peristiwa dalam novel tersebut. Sehubungan dengan itu, kajian rintis perlu di lakukan bagi merungkai permasalahan tersebut. Adakah benar novel remaja berunsur sains tidak mempunyai nilai estetik dan terhasil daripada khayalan penulis semata? Inilah yang akan di bincangkan dalam kajian ini dengan meneliti unsur sains dan sastera dalam novel remaja Tawanan Komander Caucausus (2010) karya Ruzaini Yahya dan Di Sebalik Dinara (2012) karya Dayang Noor.

\section{OBJEKTIF KAJIAN}

1. Mengklasifikasi unsur sains dan sastera yang terdapat dalam novel remaja terpilih.

2. Menganalisis unsur sains dan sastera yang terdapat dalam novel remaja terpilih berdasarkan teori

Sistem Pemikiran Bersepadu 4K (SPB4K).

3. Merumuskan unsur sains dan sastera yang dominan dalam novel remaja terpilih.

\section{SOROTAN KAJIAN MENGENAI NOVEL REMAJA}

Berdasarkan penelitian terdapat beberapa pengkaji yang telah menjalankan kajian berkaitan novel remaja. Antaranya ialah Maisarah Yaacob (2017) menyiapkan tesis kedoktoran beliau di Universiti Putra Malaysia yang berjudul Unsur Tarbiah dalam Novel Komsas. Dalam tesis ini, Maisarah menganalisis unsur tarbiah terhadap 19 buah novel KOMSAS mengikut sembilan unsur tarbiah dan terbahagi kepada dua aspek utama iaitu Hubungan Manusia dengan Allah (Habl' min Allah) dan Hubungan Manusia dengan Manusia (Habl' min al-Nas) seperti yang digariskan dalam Teori Takmilah. Menerusi kajian ini, Maisarah hanya mengupas mengenai unsur sastera yang dikaitkan dengan keagamaan sahaja dan tidak menyentuh mengenai unsur sains.

Seterusnya pengamatan dilakukan dengan meneliti kajian Nurhamizah Hashim (2015) menyiapkan tesis kedoktoran beliau di Universiti Malaya yang berjudul Psikologi Keperluan Remaja dalam Novel-Novel Remaja Hadiah Sastera Kumpulan Utusan (HSKU). Dalam tesis ini, Nurhamizah hanya memfokuskan terhadap keperluan psikologi remaja seperti keperluan fisiologi, keperluan keselamatan, keperluan kasih sayang dan cinta, keperluan penghargaan kendiri dan keperluan penyempurnaan kendiri. Kajian yang dilakukan Nurhamizah ini berkaitan dengan keperluan psikologi remaja yang tidak dikaitkan dengan unsur sains dan sastera.

Kemudian, penelitian beralih kepada kajian di peringkat sarjana yang dilakukan oleh Faziela Abu Bakar@ Che Din (2016) berjudul Unsur Emosi dan Konflik dalam novel KOMSAS Pilihan di Universiti Putra Malaysia. Kajian Faziela memfokuskan terhadap aspek emosi dan konflik. Dalam tesis ini, Faziela 
mendedahkan bahawa novel KOMSAS memaparkan dua unsur emosi iaitu emosi positif dan negatif. Manakala unsur konflik pula melibatkan konflik remaja dengan keluarga, konflik remaja dengan diri sendiri dan konflik remaja dengan rakan sebaya. Kajian Faziela ini melihat unsur psikologi yang tidak dikaitkan dengan unsur sains.

Selanjutnya, kajian Rosnani Md Zain dan Nik Rafidah Nik Muhamad Affendi berjudul Pemikiran dalam Novel Pantai Kasih (2019) yang diterbitkan dalam jurnal Rampak Serantau. Kajian yang dilakukan ini memfokuskan terhadap aspek pemikiran pengarang seperti pemikiran kekeluargaan, gejala sosial, kelas sosial, etika dan keagamaan. Kajian yang dilakukan ini hanya meneliti unsur sastera dari aspek pemikiran sahaja dan tidak dikaitkan dengan unsur sains.

Seterusnya, kajian yang dilakukan oleh Kamariah Kamarudin (2017) yang berjudul Mau'izah Remaja dalam Novel Satu Bulan Tiga Bintang Karya Ummu Hani Abu Hassan dalam Persidangan Antarabangsa Sains Sosial \& Kemanusiaan. Dalam kajian ini, Kamariah menganalis mau'izah atau dalam bahasa yang lebih mudah ialah usaha nasihat dan menasihati, usaha sentiasa pesan dan memesan ke arah kebaikan, kebenaran dan kesabaran. Hasil kajian mengemukakan usaha menasihati dan berpesan kepada kebaikan, kebenaran dan kesabaran telah menjadikan konsep mau'izah sebagai syarat utama dalam pembentuk peribadi remaja. Kajian Kamariah ini lebih menjurus kepada aspek sastera dari segi keagamaan dan tidak dikaitkan dengan unsur sains.

Menerusi pengamatan ini, pengkaji mendapati bahawa belum ada kajian-kajian lepas yang meneliti unsur sains dan sastera dalam novel remaja. Pengkaji hanya menemui unsur sastera sahaja yang diteliti oleh kebanyakan pengkaji. Antara unsur sastera tersebut ialah emosi, konflik, pemikiran, keperluan psikologi dan unsur-unsur keagamaan. Sehubungan dengan itu, kajian yang akan dilakukan ini menganalisis unsur sains dan sastera yang terdapat dalam dua buah novel remaja iaitu Tawanan Komander Caucasus (2010) karya Ruzaini Yahya dan Di Sebalik Dinara (2012) karya Dayang Noor.

\section{METODOLOGI KAJIAN}

Kajian ini menggunakan kaedah kepustakaan dan kaedah analisis teks. Kaedah kepustakaan digunakan bagi mengumpul data atau maklumat mengenai aspek kajian. Manakala kaedah analisis teks pula dilakukan setelah maklumat dan data yang diperolehi mencukupi bagi melengkapkan sebuah kajian ilmiah. Dalam kajian ini, teks yang digunakan ialah Tawanan Komander Caucasus (2010) karya Ruzaini Yahya dan Di Sebalik Dinara (2012) karya Dayang Noor. Kedua-dua novel ini dipilih berdasarkan kepada beberapa kriteria. Pertama, Tawanan Komander Caucasus merupakan pemenang tempat ketiga dalam Sayembara Fiksyen Sains dan Teknologi anjuran UTM dan Kumpulan Utusan pada tahun 2010, sementara Di Sebalik Dinara pula pemenang Hadiah Penghargaan dalam Sayembara Fiksyen Sains dan Teknologi pada tahun 2012. Kedua, novel ini merupakan teks KOMSAS. Novel Tawanan Komander Caucasus merupakan teks KOMSAS bagi Tingkatan 3 untuk zon 2 iaitu Selangor, Negeri Sembilan, Wilayah Persekutuan Kuala Lumpur dan Wailayah Persekutuan Putrajaya. Sementara novel Di Sebalik Dinara untuk pelajar Tingkatan 4 bagi zon 3 iaitu Johor, Sabah, Sarawak dan Wilayah Persekutuan Labuan. Ketiga, kerana bersesuaian dengan judul kajian iaitu mengkaji unsur sains dan sastera dalam novel remaja. Bagi melengkapkan sebuah kajian ilmiah, pengkaji akan menggunakan Teori Sistem Pemikiran Bersepadu 4K (SPB4K) bagi mengukuhkan analisis kajian.

Teori ini pada awalnya dikenali sebagai SPB4L yang diperkenalkan oleh tokoh sarjana di Universiti Penguruan Sultan Idris (UPSI) iaitu Mohd Yusof Hasan pada tahun 2001. Kemudian pada tahun 2004, teori ini dikenali sebagai Sistem Pemikiran Bersepadu 4K. Menurut Mohd Yusof Hasan, teori ini mementingkan konsep kesepaduan antara keempat-empat pemikiran tersebut. Konsep 4K terdiri daripada Kerohanian, Kebitaraan, Kesaintifikan dan Kekreatifan. Keempat-empat kemahiran pemikiran ini perlu dimiliki secara seimbang dan bertimbal balik dan bukannya secara berasingan (Mohd Yusof Hasan, 2001). 
Pemikiran Kerohanian merupakan pemikiran yang amat suci, luhur dan tinggi martabatnya. Pemikiran ini berhubungan dengan keimanan, ketauhidan dan kepercayaan manusia terhadap keesaan dan kebesaran Allah SWT. Pemikiran Kerohanian ini turut melihat dwiperanan manusia sebagai hamba dan khalifah Allah SWT. Pemikiran ini akan melahirkan manusia soleh atau solehah (Mohd Yusof Hasan, 2007).

Pemikiran Kebitaraan ialah pemikiran yang berkaitan dengan peranan akal dan minda manusia dengan berteraskan kebijaksanaan atau kebestarian. Pemikiran ini membawa manusia ke arah kegemilangan dan kecemerlangan dalam hidup. Pemikiran ini khusus untuk satu peringkat awal kejadian manusia, iaitu daripada kandungan rahim hingga kepada umur kanak-kanak. Dalam agama Islam, ia mementingkan asas kekeluargaan yang bermula daripada perkahwinan manusia, hubungan suami isteri, mengandung, penjagaan pendidikan asas semasa bayi dan pendidikan kanak-kanak. Oleh hal yang demikian, penggunaan pemikiran kebitaraan dalam karya sastera adalah untuk memperlihatkan dan menampilkan watak-watak yang cemerlang, bijaksana, bestari dan hebat (Mohd Yusof Hasan, 2007).

Pemikiran Kesaintifikan merupakan pemikiran yang bersifat logik, saintifik yang membawa kepada kebenaran, kepastian, ketepatan dan kegunaan fakta dan angka. Dalam komunikasi sehari-hari sesama manusia, kegiatan dalam penulisan dan pembacaan, pertuturan dan pendengaran, manusia perlu menggunakan ilmu logik. Logik ialah proses penaakulan yang membawa kepada keputusan seperti idea, fakta atau keputusan. Ilmu logik ialah keseluruhan proses yang membawa kepada keputusan melalui penakulan yang berdasarkan bukti-bukti yang jelas dan konkrit. Siti Khariah Mohd Zubir (2011) mengatakan bahawa melalui penghasilan sesebuah karya yang berteraskan pemikiran kesaintifikan, sesebuah karya haruslah mengemukakan latar belakang yang sebenar atau benar-benar wujud, menggunakan latar tempat yang indah permai, suasana yang kondusif, latar masa yang sesuai, fakta yang jelas, nada yang positif, zaman yang relevan dan waktu yang jelas.

Pemikiran Kekreatifan sangat berguna bagi pembinaan idea baharu, pembaharuan dalam perkembangan produksi dan sistem pemasaran, penyelesaian masalah dan ambilan keputusan, pengkajian data daripada pelbagai sudut untuk mendapat maklumat yang berguna, dan pencarian jalan bagi menyempitkan perbezaan pendapat dalam kalangan manusia dan konsep. Hal ini selari dengan pendapat Siti Khariah Mohd Zubir (2008) mentakrifkan bahawa pemikiran kreatif sebagai suatu pemikiran yang berkemampuan mencipta sesuatu yang baharu.Oleh itu, manusia perlu mempunyai sifat lateral, kreatif, inovatif, subjektif, memberi idea dan pendapat serta bersifat estetik dan falsafah. Pemikiran jenis ini tercetus dari hemisfera otak kanan atau hoka yang bersifat sastera dan seni. Pemikiran ini melahirkan insan yang sensitif, ceria, berjenaka dan optimis dalam kehidupan. Menurut Mardzelah Makhsin (2007), individu yang mempunyai pemikiran kekreatifan dianggap sebagai individu yang spontan dan sanggup mengambil risiko serta melakukan kesilapan. Mereka juga dianggap sebagai orang yang dapat menerima idea-idea dan pengalaman yang baru. Justeru, Mohd Yusof Hasan (2007) mengatakan bahawa pemikiran ini lebih mementingkan aspek kreativiti, imaginasi, rekaan dan khayalan, seni dan estetika. Ini bermakna pemikiran ini melihat aspek teknik, bentuk visual dan stail (gaya bahasa) dalam karya sastera.

Relevan penggunaan teori Sistem Pemikiran Bersepadu 4K (SPB4K) di dasarkan kepada keseimbangan di antara pemikiran hoka (sains) dan hoki (sastera) yang bertepatan dengan aspek kajian iaitu menganalisis unsur sains dan sastera dalam novel remaja. Oleh yang demikian, teori ini dipercayai dapat mengubah persepsi negatif yang mengatakan bahawa sains dan sastera tidak mungkin bersatu dalam sesebuah karya kreatif. Kesepaduan prinsip-prinsip dalam teori ini juga iaitu pemikiran kerohanian, kebitaraan, kesaintifikan dan kekreatifan amat relevan dalam menghujahkan aspek yang ingin dikaji.

\section{ANALISIS PERBINCANGAN}

Analisis perbincangan ini akan dipecahkan kepada dua bahagian. Bahagian pertama, unsur sains yang terdapat dalam novel Tawanan Komander Caucasus (2010) karya Ruzaini Yahya dan Di Sebalik Dinara (2012) karya Dayang Noor. Antara unsur sains yang akan dibincangkan seperti sains gunaan dan sains zoologi. Bahagian kedua, analisis diteruskan dengan meneliti unsur sastera yang terdapat dalam kedua- 
dua novel tersebut. Antara unsur sastera yang akan diteliti seperti pemikiran, nilai murni, emosi dan gaya bahasa.

\section{1) Unsur Sains}

Istilah atau perkataan sains dalam bahasa Inggeris science adalah istilah baru yang diperkenalkan bersama kelahiran sains Barat sekitar kurun ke-15 Masihi. Istilah science berasal daripada perkataan Latin iaitu scientie, kemudian daripada perkataan scienta yang bermaksud pengetahuan digunakan pakai dalam mendefinisikan istilah sains. Tetapi tidak semua pengetahuan boleh dianggap sebagai pengetahuan sains. Menurut Shaharir Mohamad Zain (1987) pengetahuan yang maklumatnya (hasil daripada pengamatan fenomena alam tabii) dijana dan dikembangkan secara bersistem dengan kaedah-kaedah tertentu berdasarkan premis tertentu oleh pencerapnya sehingga menumpukan pengetahuan yang boleh dipercayai, sama ada melalui eksperimen atau hujah mantik secara teori. Berdasarkan pendefinisian tersebut, sains merupakan pengetahuan yang dapat dibuktikan secara emprikal, kesahihan data melalui eksperimen dan dikukuhkan lagi dengan penggunaan teori dalam mengungkapkan fenomena alam tabii. Dalam kajian ini, unsur sains yang didapati seperti sains gunaan dan sains zoologi.

Ilmu sains yang diketengahkan dalam novel Di Sebalik Dinara (2012) karya Dayang Noor berkaitan dengan sains gunaan. Dalam ilmu sains, kaedah pengecaman DNA ini dikategorikan di bawah sains forensik. Menurut Ann Fullick (2010), DNA ialah bahan yang membawa 'cetakan biru' hidup. DNA dijumpai di dalam nukleus sel badan dan mengandungi maklumat yang diwarisi daripada ibu bapa. DNA banyak mempengaruhi dalam menentukan rupa fizikal dan sikap seseorang sebagai manusia. Misalnya dalam novel kaedah DNA digunakan oleh Dr Maxi untuk mengecam Farisha sebagai individu yang dicari selama ini. Dua kaedah yang digunakan untuk mengecam Farisha ialah melalui teknik cap jari dan DNA. Dalam buku Sains Forensik, Ann Fullick (2010) mendefinisikan cap jari sebagai corak rabung pada kulit hujung jari. Cap jari terbentuk sebelum manusia dilahirkan lagi, iaitu semasa manusia terbentuk di dalam rahim ibu. Cap jari seseorang individu tidak pernah berubah seumur hidup kecuali sekiranya hujung jari mengalami kecederaan teruk. Cap jari membentuk satu daripada tiga corak asas, iaitu pusaran, gelungan dan lengkungan. Di dalam setiap corak asas tersebut pula terdapat variasi kecil yang dikenali sebagai titik butir terperinci. Titik butir terperinci bermaksud variasi kecil yang terdapat pada corak cap jari asas yang unik untuk setiap individu. Setiap individu pula tidak mempunyai persamaan susunan titik butir terperinci, walaupun corak asasnya serupa pada jari mereka. Pembentukan cap jari selepas menyentuh sesuatu benda adalah disebabkan kesan peluh dan minyak daripada badan. Oleh sebab itu, cap jari seseorang mudah dikesan dengan menggunakan beberapa jenis kimia yang sesuai dan akhirnya dapat mengenal pasti identiti orang yang dicari. Hal ini dapat dilihat melalui petikan di bawah:

\section{Dr. Maxi meneliti cawan kecil di dalam bungkusan. Terdapat sedikit kesan gincu berwarna merah jambu dan kesan air liur yang semakin menghilang. Dua cap jari kelihatan agak jelas.}

(Di Sebalik Dinara, 2012:14)

Seterusnya ialah melalui kaedah DNA (asid deoksiribonukleik) merupakan salah satu kaedah atau teknik dalam penyiasatan sains forensik ini. Menurut Ann Fullick (2010), DNA ialah bahan yang membawa 'cetakan biru' hidup.DNA dijumpai di dalam nucleus sel badan dan mengandungi maklumat yang diwarisi daripada ibu bapa.DNA banyak mempengaruhi dalam menentukan rupa fizikal dan sikap seseorang sebagai manusia.DNA juga bermaksud molekul yang sangat panjang dengan bentuk yang cantik dan terbina daripada empat subunit yang berbeza dan bergabung dalam gabungan yang pelbagai.DNA juga saling berkaitan dengan bidang sains yang lain iaitu bidang kimia, biologi dan kejuruteraan genetik. Menurut Ann Fullick (2010), kesan darah, air mani, air liur, kulit, rambut dan beberapa kesan lain mampu menghasilkan DNA yang boleh digunakan untuk mengenal pasti seseorang terutamanya penjenayah.Dalam novel Di Sebalik Dinara, pengarang jelas membuktikan bahawa proses 
DNA yang dilakukan melalui kesan air liur Farisha telah menunjukkan bahawa Farisha ialah orang yang dicari Dr. Maxi selama ini. Hal ini dapat dijelaskan melalui petikan di bawah:

'Saya dah buat ujian DNA pada kesan air liur yang melekat di cawan ini. Positif. Dia memang orang yang kita cari-cari”, kata Aqram.

(Di Sebalik Dinara, 2012:14)

Berdasarkan kaedah DNA yang digunakan dalam novel tersebut jelas membuktikan bahawa pengarang menyatakan maklumat tersebut berdasarkan fakta sains yang tepat. Lazimnya kaedah DNA digunakan untuk mengesan waris seperti yang dilakukan oleh Dr. Maxi. Keputusan DNA menerusi air liur dan cap jari tersebut membuktikan bahawa Farisha merupakan anak kandung, Karl. Ini dijelaskan oleh Tengku Sifizizul dan Ahmad Sofiman (2004) bahawa DNA ialah molekul biologi yang bertanggungjawab sebagai elemen pewarisan dan juga sebagai agen pembawa informasi atau maklumat genetik. Ia juga adalah molekul perantara utama dalam semua aspek metabolism sel dan DNA memainkan peranan penting sebagai bahan genetik. Hal ini bersesuaian dengan pemikiran kesaintifikan yang dinyatakan oleh Mohd Yusof Hasan (2007) sebagai pemikiran yang bersifat logik, saintifik yang membawa kepada kebenaran, kepastian, ketepatan dan berdasarkan bukti-bukti dan fakta yang tepat.

Seterusnya, dalam novel Tawanan Komander Caucasus (2010) karya Ruzaini Yahya mengetenghkan ilmu sains zoologi. Istilah zoologi berasal dari perkataan Greek, iaitu "haiwan" (zoo) dan "pengetahuan" (logos) (Kamarul Azmi Jasmi, 2013). Zoologi membawa maksud kajian mengenai haiwan termasuk klasifikasi, struktur, fisiologi dan sejarah (Collins English Dictionary, 2009). Secara ringkas dapat difahami bahawa zoologi adalah bidang sains yang mengkaji mengenai kelompok benda hidup yang dikenali sebagai haiwan. Dalam konteks kajian ini, bidang sains zoologi dapat dikesan dalam novel Tawanan Komander Caucasus ialah berkaitan dengan spesis kumbang. Kumbang merujuk kepada sejenis serangga yang berkepak dan berkulit keras. Antara spesis kumbang yang diketengahkan dalam novel tersebut seperti Coleopetra. Perkataan Coleopetra berasal dari kata coleos yang bererti sesungut dan pteron yang bererti sayap maka dapat disimpulkan Coleoptera adalah serangga yang memiliki sesungut pada sayapnya. Berdasarkan kajian yang dilakukan, Kamarul Azmi menambah empat puluh peratus dari seluruh spesies serangga adalah kumbang (sekitar 350,000 spesies) dan spesies baru masih belum ditemukan.

Menurut Hari Purnomo (2010) Coleopetra memiliki sayap depan yang keras, tebal dan merupakan pelindung bagi sayap belakang dan tubuhnya. Sayap hadapan dikenali sebagai elitron. Ketika terbang sayap depan kumbang tidak berfungsi hanya sayap belakang yang digunakan untuk terbang. Sayap belakang pula dikenali sebagai elitra dan mempunyai selaput. Mulut atau muncung kumbang pula jenis penggigit dan pengunyah, kumbang juga memiliki kepala yang bebas dan kadang memanjang ke hadapan atau ke bawah serta memiliki sepasang mata yang besar. Penjelasan mengenai ciri-ciri Coleopetra dapat dibuktikan melalui petikan di bawah:

Puteri Coleopetra mempunyai cangkerang yang cantik sekali. Cangkerangnya berwarna kehijauan dan berkilat. Sekali-sekala bagaikan bercahaya pula. Sesungutnya pula panjang, tentunya berfungsi sebagai deria bau yang sensitif baginya.

(Tawanan Komander Caucasus, 2010:87)

Spesis kumbang yang seterusnya ialah lampyridae. Kata lampyridae berasal dari bahasa Yunani iaitu lampuris ertinya ulat bersinar. Hari Purnomo (2010) mengatakan bahawa lampyridae juga di kenali sebagai lalat api atau kunang-kunang. Betina yang telah dewasa bentuknya tetap seperti larva, sedangkan yang jantan berbentuk seperti kumbang. Tetapi kedua-dua spesis ini mempunyai badan yang bersinar. Organ yang bersinar itu tersusun dari sel-sel yang mengandungi lemak yang banyak, urat saraf dan pembuluh darah yang paling kecil iaitu tracheae. Trachea ini berfungsi untuk menghasilkan sinar atau cahaya. Hal ini dapat dilihat melalui petikan berikut: 
Kami dipanggil Lampyridae dalam bahasa Latin. Maksudnya "Api yang bercahaya". Bara tibatiba bersuara. "Kadang-kadang keluargaku juga dipanggil kunang-kunang", terangnya penuh bangga.

\section{(Tawanan Komander Caucasus, 2010:40)}

Berdasarkan petikan di atas, pengkaji mendapati bahawa pengarang tidak mereka-reka fakta berkaitan bentuk fizikal spesis kumbang yang ditokok tambah dengan imaginasi pengarang tetapi informasi yang di berikan dapat dibuktikan kesahihanya. Penerapan ilmu bantu mengenai spesis kumbang ini telah memberi ilmu yang bermanfaat kepada remaja. Hal ini jelas dinyatakan oleh Shahnon Ahmad (1991) bahawa sastera yang baik ialah sastera yang dapat mendidik manusia kerana perkataan sastera itu sendiri membawa maksud akliah atau ilmu. Hal ini juga bersesuaian dengan pendapat Mohd Yusof Hasan (2007) yang mengatakan bahawa dalam pembinaan sesebuah karya sastera sewajarnya mengandungi pemikiran kesaintifikan yang bersifat logik, saintifik yang membawa kepada kebenaran, kepastian, ketepatan dan berdasarkan bukti-bukti dan fakta yang tepat.

\section{2) Unsur Sastera}

\section{Pemikiran}

Sebagai mana yang diketahui, pemikiran berasal dari kata bahasa Arab yang membawa makna berfikir yakni melibatkan proses berfikir. Dalam hal ini, S. Othman Kelantan (1997) berpandangan bahawa kalimat Arab iaitu fikrun yang bermaksud fikiran daripada kata akar fakara, yafkiru, fakkara, taffakra dan iftakara yang bererti memikir perkara itu, memikirkan sesuatu atau fikkir, faikar, yang bererti banyak berfikir atau tafakur yang membawa erti hal-hal tentang berfikir. Pemikiran merupakan satu juzuk penting kepada pengarang dalam karya-karya mereka untuk diratapi, dibaca, direnungi oleh pembaca. Ini selari dengan pendapat Baha Zain (1991) yang mengatakan pemikiran ialah satu perkara yang dianggap sebagai induk atau nadi yang menghidupkan perjuangan mereka menerusi hasil-hasil seninya. Kepelbagaian pemikiran atau gagasan yang diutarakan oleh seseorang penulis dalam menyampaikan amanat merupakan sesuatu yang menarik untuk dihalusi oleh pembaca. Sejajar dengan itu, kajian ini akan memperincikan pemikiran utama pengarang dalam menyampaikan amanat, pesan atau nasihat kepada pembaca.

Dalam novel Di Sebalik Dinara (2012), pengarangnya Dayang Noor menyampaikan pemikiran mengenai kerakusan sikap manusia yang terlalu mengejar perkembangan sains dan teknologi sehingga melupakan nilai-nilai kemanusiaan.Dalam novel tersebut menerusi watak Karl yang digambarkan sebagai pencipta sains dan teknologi menyalahgunakan akal fikiran dan tidak mempunyai sifat kemanusiaan apabila dia bertindak menanam pelbagai implant dalam tubuh badan anaknya Farisha. Pada ketika itu, Farisha yang masih kecil tidak dapat menahan penderitaan akibat daripada pembedahan implan yang dilakukan oleh ayahnya tanpa disuntik dengan ubat bius terlebih dahulu. Karl berhasrat menjadikan Farisha seorang kanak-kanak yang genius menerusi pembedahan implan tersebut. Kerakusan Karl mendorong Dr. Maxi, iaitu pembantunya menyelamatkan Farisha dan di serahkan kepada keluarga angkat. Sikap Karl ini menyebabkan Farisha terpisah daripada ibu bapa kandung dan dia tidak mengetahui status dirinya sebagai anak angkat keluarga Azraai. Farisha juga dilahirkan tanpa ikatan perkahwinan antara Karl dan Medina. Dalam novel tersebut, pengarang menekankan bahawa ketaksuban manusia terhadap sains dan teknologi menyebabkan keruntuhan sesebuah institusi kekeluargaan dan yang paling menyedihkan anak-anak yang menjadi mangsa. Situasi tersebut dapat dilihat dalam petikan berikut:

"Kerana dia taksub dengan sains. Dia mahu korbankan Isha demi sains".

(Di Sebalik Dinara, 2012:180) 
Pemikiran yang diungkapkan dalam novel Tawanan Komander Caucasus (2010) karya Ruzaini Yahya mengenai kerakusan sikap segelintir manusia yang mengejar sains dan teknologi sehingga mengabaikan keseimbangan ekosistem. Hal ini berlaku demikian kerana manusia yang digelar saintis menjadikan serangga atau haiwan sebagai bahan uji secara berlebihan. Sikap seperti inilah yang menyebabkan spesis kumbang berdendam dengan manusia sehingga menculik Farhani dan Kim Yang. Petikan di bawah menjelaskan situasi tersebut:

"Ooo... cukup serik, tapi itulah pengajaran buat kami, makhluk manusia yang selalu bertindak konon atas kemajuan sains. Kami tak pernah menyelami perasaan makhluk lain yang terkurung di dalam tabung uji. Maafkan kami, ya..." Kim Yang pula menyatakan isi hatinya.

(Tawanan Komander Caucasus, 2010:157)

Berdasarkan petikan kedua-dua novel tersebut jelaslah bahawa kerakusan manusia mengejar sains dan teknologi kerana kepentingan diri dan tidak memahami konsep keterikatan antara hukum (Islam) dengan etika. Hal ini selari dengan pendapat Iman Musbikin (2012) yang mengatakan bahawa keterkaitan antara hukum (agama Islam) dan etika sangat penting kerana hukum sebenarnya ialah amalan sikap tindakan etika. Apabila etika dan moral selalu mendahului atau merupakan sendi dasar kemajuan ilmu pengetahuan dan teknologi, maka hukum dan peraturan sebagai amalan tindakan etika dan moral selalu akan tertinggal oleh kemajuan sains dan teknologi. Sehingga mereka yang sememangnya sudah mempunyai moral yang rendah sering melakukan tindakan yang tidak beretika kerana selalu mempersoalkan aturan hukum Allah dan tidak mempersoalkan pada dirinya sendiri adakah tindakannya beretika atau tidak. Hal ini kerana, Islam menganjurkan kesan sains ataupun teknologi yang dihasilkan adalah serasi dengan kehidupan makhluk dan perjalanan alam tabii. Dengan sebab itu akan tercapailah matlamat kesejahteraan dan kebahagiaan hidup di dunia ini. Sebaliknya aktiviti sains yang berlawanan dengan prinsip keadilan merupakan kezaliman yang akan membawa keburukan dan kehancuran kepada manusia dan alam seluruhnya sebagaimana yang kita alami sekarang ini hasil daripada sains barat yang menyimpang daripada prinsip-prinsip keadilan sejagat. Oleh yang demikian, bentuk sains Islam adalah bersifat sosial, alamiah dan rohaniah (Muhammad Yusuf Khalid, Syamsul Bahri Andi Galigo dan Mohd Radhi Ibrahim 2005). Hal ini juga berlaku kerana manusia tidak mempunyai ciri-ciri pemikiran kerohanian seperti yang dinyatakan oleh Mohd Yusof Hasan (2007) berteraskan keimanan, ketauhidan dan kepercayaan manusia terhadap keesaan Allah SWT.

\section{Nilai Murni}

Nilai-nilai murni merangkumi aspek tingkah-laku yang baik, peradaban dan tatasusila seseorang individu dalam hubungan sesama manusia, alam sekitar, dan Tuhan. Nilai-nilai murni dalam karya sastera pula berfungsi untuk menghibur, malahan mendidik remaja dalam mengharungi usia peralihan itu. Antara nilai-nilai murni yang sering ditekankan dalam novel-novel remaja ialah rajin, tekun, baik hati, berusaha, berbudi bahasa, bersopan santun, saling menghormati, bertanggungjawab, bertindak dengan rasional, tidak mementingkan diri sendiri dan rasional. Dalam hal ini, Abdul Ahmad (1991) menegaskan bahawa nilai-nilai murni seperti yang dinyatakan harus ditekuni oleh penulis dalam sesebuah karya sastera agar kesannya dapat mengangkat jati diri remaja sebagai warga yang terdidik dengan akhlak-akhlak mulia dan dapat berganding bahu menyumbang kepada pembangunan negara, bangsa dan juga agama. Dalam konteks kajian ini, antara nilai-nilai murni yang akan dibincangkan seperti sopan santun atau berbudi pekerti, hormat-menghormati dan tolong-menolong.

Misalnya dalam novel Di Sebalik Dinara (2012), pengarangnya Dayang Noor mengetengahkan watak Akram yang mempunyai keperibadian yang baik, iaitu bersopan santun atau berbudi pekerti. Secara umumnya, sopan santun atau berbudi pekerti merujuk kepada tingkah laku manusia yang baik, sopan dan bermoral. Dalam masyarakat Melayu, nilai murni ini amat dituntut bagi melahirkan sebuah masyarakat yang harmoni dan saling hormat-menghormati. Dalam novel tersebut, pengarang jelas 
mengetengahkan watak Akram yang digambarkan sebagai seorang yang mempunyai budi pekerti yang tinggi kerana menggunakan bahasa yang sopan ketika menegur seorang perempuan yang bercakap kuat sehingga menggangu orang lain ketika berada di lapangan terbang. Teguran Akram sedikit pun tidak mengguriskan perasaan wanita tersebut, malah wanita itu tersenyum malu kerana baru tersedar yang perbuatannya telah menganggu orang lain. Hal ini dapat dibuktikan melalui petikan berikut:

Farisha tertarik apabila mendengarkan tutur kata lelaki itu yang begitu sopan, teratur dan bijak sekali dia menyusun ayat dan kata.

(Di Sebalik Dinara, 2012:2)

Hal ini juga dapat dilihat dalam novel Tawanan Komander Caucasus (2010) yang mengetengahkan nilai murni bersopan santun atau berbudi pekerti menerusi watak Farhani. Dalam novel tersebut, Farhani digambarkan sebagai seorang remaja yang sangat menjaga tutur kata dan perbuatan semasa menunjukkan cecair izrael endosulfan kepada Dara Merah. Hal ini kerana, cecair izrael endosulfan merupakan racun yang sangat digeruni oleh spesis kumbang kerana cecair tersebut digunakan oleh manusia untuk menghapuskan kumbang-kumbang yang merosakkan tanaman mereka. Oleh itu, Farhani berhati-hati dalam menuturkan kata-kata agar Dara Merah tidak tersinggung. Ini dapat dibuktikan melalui petikan berikut:

Dia bimbang mereka akan tersinggung apabila melihatnya kelak. Dia perlu berhati-hati seperti yang dipesan oleh orang tua-tua, umpama menarik rambut di dalam tepung, tepung jangan berserak, rambut jangan putus. Akhirnya, setelah mempertimbangkan dengan mendalam akan hal itu, dia pergi menemui Dara Merah. Dia ingin menunjukkan botol itu kepadanya biarpun dia menyedari cecair izrael endosulfan dapat mengancam nyawa mana-mana spesis kumbang.

(Tawanan Komander Caucasus, 2010:133-134)

Justeru, dalam hal ini Yaacob Haron (1991) menegaskan bahawa pendidikan awal kanak-kanak bermula dari rumah. Ibu bapa dianggap sebagai guru pertama kepada anak-anak dalam memberikan didikan yang sempurna. Didikan dari awal kanak-kanak akan membentuk imej remaja yang bersopan santun dan berbudi pekerti setelah mereka dewasa kelak. Ini juga selari dengan pendapat Mohd Yusof Hasan (2007) sebagai Pemikiran Kerohanian yang berteraskan keimanan, ketauhidan dan kepercayaan manusia terhadap Allah SWT. Hanya manusia yang memiliki pemikiran kerohanian sahaja yang akan melakukan suruhan dan meninggalkan laranganNya seperti bersopan santun dan berbudi pekerti.

Nilai murni yang seterusnya ialah hormat-menghormati.Budaya orang Melayu menganjurkan nilai saling hormat-menghormati antara satu sama lain.Dalam hal ini, masyarakat Melayu digalakkan untuk memberi penghormatan terlebih dahulu kepada orang lain seperti memberi salam dan berjabat tangan. Orang yang tidak membalas penghormatan yang diberikan akan dipandang rendah terutamanya dalam masyarakat Melayu itu sendiri. Nilai hormat-menghormati ini misalnya dapat dikesan dalam novel Di Sebalik Dinara (2012) karya Dayang Noor. Dalam novel tersebut, pengarang jelas memaparkan watak Farisha yang amat sayang dan menghormati dengan bersalaman dan memeluk erat abangnya, Azraai. Ini dapat dilihat melalui petikan di bawah:

"Isha dah sampai?" tegur Azraai. Isha bangun dari sofa lalu bersalaman dengan abangnya.

(Di Sebalik Dinara, 2012:119)

Sehubungan dengan itu, Rosnani Md Zain dan Nik Rafidah Nik Muhamad Affendi (2017) dalam kajian mereka menegaskan bahawa nilai hormat-menghormati sewajarnya diteruskan oleh generasi akan datang dalam melahirkan masyarakat Malaysia yang harmoni dan bersatu-padu. 
Selain menghormati ahli keluarga, masyarakat Melayu juga mengamalkan nilai menghormati tetamu. Menurut ajaran agama Islam, tetamu hendaklah dilindungi, dimuliakan dan dilayan sebaik mungkin, malah tuan rumah dituntut agar berkorban dan tidak mementingkan diri sendiri demi menjaga dan menghormati tetamu. Oleh yang demikian, tetamu sentiasa dipandang baik oleh masyarakat Melayu dan diraikan dengan sebaik-baiknya meskipun tetamu tersebut orang yang tidak disenangi. Dalam novel Tawanan Komander Caucasus (2012) karya Ruzaini Yahya memaparkan nilai murni masyarakat melayu yang melayan baik tetamu dapat dilihat menerusi watak Puan Asmah iaitu ibu kepada Farhani. Kunjungan Cikgu Salimah di sambut baik oleh Puan Asmah dengan menghidangkan minuman dan makanan. Puan Asmah juga tidak pernah menyalahkan Cikgu Salimah atas kehilangan anaknya ketika mencari spesis kumbang di dalam hutan. Ini dapat dilihat dalam petikan di bawah:

Perlahan-lahan Puan Asmah menaiki anak-anak tangga dari ruang dapur yang terdapat di tingkat bawah.Dia menatang dulang berisi kuih dan cawan-cawan yang masih kosong.Selesai dia meletakkan dulang di atas meja, dia kembali ke dapur untuk mengambil teko.

(Tawanan Komander Caucasus, 2010:55)

Budaya menghormati tetamu ini diakui sendiri oleh sarjana Barat iaitu Isabella Bird dalam (Laurent Metzger, 2007) yang pernah melawat Sememanjung pada abad ke-19 yang menyatakan bahawa "Hospitality is one of the Malay virtues". Kenyataan ini jelas menunjukkan bahawa orang Melayu mempunyai sikap suka meraikan tetamu.

Justeru, pemaparan sikap Farisha dan Puan Asmah dalam kedua-dua buah novel tersebut membuktikan mereka merupakan watak yang mempunyai Pemikiran Kebitaraan seperti yang disarankan oleh Mohd Yusof Hasan (2007). Menurut pemikiran ini, sesebuah karya harus menampilkan watak yang cemerlang, bijaksana, bestari dan hebat yang dapat diperoleh melalui ilmu pengetahuan. Watak-watak sebegini yang seharusnya diketengahkan oleh pengarang dalam memupuk nilai-nilai murni kepada pembaca remaja.

Nilai murni tolong-menolong turut dikesan dalam novel kajian. Secara umumnya, tolongmenolong adalah sikap saling memberi pertolongan dan menyokong antara satu sama lain. Dalam hal ini Che Bakar Che Mat, Salmah Hussin dan Wan Ariffin Wan Yon (2007) menjelaskan bahawa tolongmenolong boleh dilakukan mengikut keadaan, kemampuan yang boleh ditunaikan antaranya pertolongan dari segi harta benda dan pertolongan dari segi masa. Misalnya dalam novel Di Sebalik Dinara (2012) pengaragnya, Dayang Noor mengetengahkan nilai murni ini melalui watak Dr. Maxi yang menyelamatkan nyawa Farisha daripada menjadi mangsa korban ketaksuban bapanya, iaitu Karl. Karl menanam pelbagi implan ke dalam otak Farisha untuk menjadikan anaknya seorang yang genius. Tindakan mendatangkan kesakitan kepada Farisha yang pada ketika itu masih lagi kecik. Dr. Maxi yang tidak sanggup melihat penderitaan Farisha telah membawa Farisha ke tempat selamat kemudian diserahkan kepada keluarga angkat. Situasi tersebut data dijlelaskan dalam petikan di bawah:

"Saya yang membawa awak ke tempat selamat. Saya serahkan awak kepada keluarga angkat awak yang telah menjaga dan membesarkan awak dengan penuh kasih sayang. Kalau saya biarkan awak di Soft Lab, mungkin awak sudah mati”.

(Di Sebalik Dinara, 2012:219)

Seterusnya dalam novel Tawanan Komander Caucasus (2010) karya Ruzaini Yahya memaparkan sikap suka membantu dalam kalangan masyarakat Melayu. Hal ini jelas digambarkan menerusi sikap prihatin penduduk kampung yang menawarkan bantuan untuk mencari Farhani dan Kim Yang. Mereka ditugaskan untuk mencari spesis kumbang oleh Cikgu Salimah iaitu guru sains di sekolah tersebut. Malang menimpa apabila kedua-dua murid tersebut dikatakan hilang ketika mencari spesis kumbang di hutan. Keprihatinan sikap penduduk dapat dilihat melalui petikan berikut: 
Ramai pula yang menawarkan diri untuk mencari Kim Yang dan Farhani menggunakan ilmu batin.

(Tawanan Komander Caucasus, 2010:51)

Justeru, nilai tolong-menolong yang dipaparkan dalam kedua-dua novel tersebut juga merupakan tuntutan dalam ajaran agama Islam. Ini dapat dibuktikan menerusi firman Allah SWT seperti dalam petikan di bawah:

\begin{abstract}
"Dan hendaklah kamu bertolong-tolongan untuk membuat kebajikan dan bertaqwa, janganlah kamu bertolong-tolongan pada melakukan dosa (maksiat) dan pencerobohan.Dan bertaqwalah kepada Allah kerana sesungguhnya Allah amat berat azab seksanya (bagi sesiapa yang melanggar perintahnya)".
\end{abstract}

(Surah al-Maidah: ayat 2)

Hal ini juga selari dengan pendapat Mohd Yusof Hasan (2007) yang menjelaskan Pemikiran Kerohanian sebagai pemikiran yang berhubung dengan keimanan, ketauhidan dan kepercayaan manusia terhadap keesanaan dan kebesaran Allah SWT. Manusia yang memiliki ciri-ciri pemikiran kerohanian akan mengikut segala suruhan Allah dan meninggalkan laranganNya. Ini jelas terbukti bahawa nilai tolong menolong merupakan sebahagian daripada suruhan Allah SWT.

\title{
Emosi
}

Emosi merupakan elemen penting yang menggerakan plot atau penceritaan dalam sesebuah karya sastera. Unsur emosi menjadi penanda aras dalam membezakan antara karya sastera dengan buku-buku ilmiah. Secara umumnya, emosi ialah refleksi manusia terhadap sesuatu situasi seperti sedih, marah, gembira, takut dan sebagainya. Menurut Faziela Abu Bakar @ Che Din dan Nik Rafidah Nik Muhamad Affendi (2015) dalam kajian mereka menegaskan bahawa manusia merupakan golongan benda hidup yang mempunyai perasaan yang tinggi dan halus. Dalam hal ini, Asmad (1990) berpendapat bahawa karya sastera itu lahir daripada jiwa halus seorang seniman. Orang yang kasar jiwanya, bukan sahaja tidak dapat menghasilkan sesuatu yang indah, yang bernilai seni, bahkan dia tidak dapat merasakan keindahan yang wujud pada sesuatu hasil kesenian. Jiwa yang mudah terasa, kebiasaannya mempunyai rasa seni yang agak lebih daripada jiwa biasa.

Dalam konteks kajian ini, pengkaji mendapati kedua-dua buah novel, iaitu Di Sebalik Dinara dan Tawanan Komander Caucasus memaparkan emosi sedih. Secara umumnya, perasaan sedih dapat dikaitkan dengan unsur psikologi iaitu kekurangan, kehilangan, putus asa, tidak mampu melakukan apaapa, pilu dan marah. Kebiasaannya, manusia yang berada dalam emosi sedih akan mengalirkan air mata sebagai refleksi untuk meluahkan perasaan. Seterusnya dalam novel Di Sebalik Dinara (2012) karya Dayang Noor pemaparan emosi sedih dapat dilihat menerusi watak Farisha yang tidak menyangka bahawa dia merupakan anak angkat keluarga Azraai. Farisha diserahkan kepada keluarga angkat setelah Dr. Maxi menyelamatkannya daripada menjadi mangsa ketaksuban Karl terhadap sains dan teknologi dengan menanam pelbagai implan dalam tubuh badan untuk melahirkan Farisha yang genius. Farisha juga jatuh sakit dan menerima rawatan di hospital setelah Azraai menceritakan perkara yang sebenar. Ini jelas menunjukkan bahawa Farisha terlalu sedih dengan status dirinya yang bukan adik kandung kepada Azraai. Situasi tersebut dapat dilihat dalam petikan di bawah:

"Abang, Isha tak tahu nak cakap apa. Isha betul-betul tak bersedia untuk dengar semua ini. Farisha menggeleng-geleng. Hatinya pedih. "Mula-mula dapat tahu abang sakit. Sekarang abang beritahu Isha ni anak angkat pula. Ini terlalu berat untuk Isha terima, bang”. 
Namun demikian, Farisha berfikiran rasional dan menerima ketentuan takdir malah bersyukur kerana di besarkan dalam keluarga beragama Islam yang penuh dengan kasih sayang. Hal ini kerana Farisha merupakan anak luar nikah dan ibu bapanya bukan penganut agama Islam. Ini dapat dibuktikan melalui petikan berikut:

"Syukur, Isha diserahkan kepada ibu dan ayah. Isha membesar dalam keluarga Islam".

(Di Sebalik Dinara, 2012:177)

Seterusnya emosi sedih ini dipaparkan dalam novel Tawanan Komander Caucasus (2010) karya Ruzaini Yahya semasa menceritakan peristiwa kehilangan Farhani. Puan Asmah sebagai ibu Farhani digambarkan menitiskan air mata kerana terlalu sedih dan juga tidak keruan memikirkan nasib yang menimpa Farhani sehinggakan Puan Asmah ingin menggunakan kepakaran bomoh untuk mencari di mana Farhani berada. Ini dapat dilihat menerusi petikan berikut:

"Sabar... kita tak tahu apa sebenarnya yang berlaku. Awak tu, janganlah asyik menangis saja", balas Encik Adnan.

(Tawanan Komander Caucasus, 2010:30)

Setelah di pujuk oleh suaminya, Puan Asmah mula berfikiran rasional dan menganggap kehilangan Farhani sebagai satu hikmah yang dikurniakan oleh Allah SWT. Ini dapat dikesan dalam petikan di bawah:

"Kami tahu, cikgu tak bermaksud buruk. Cuma takdir Farhani saja yang mungkin kurang baik. Mungkin ada hikamh yang ingin Dia berikan kepada kami".

(Tawanan Komander Caucasus, 2010: 52-53)

Dalam hal ini jelas menunjukkan bahawa watak Puan Asmah dan Farisha mempunyai Pemikiran Kerohanian seperti yang ditegaskan oleh Mohd Yusof Hasan (2007) sebagai pemikiran yang berteraskan keimanan, kepercayaan dan ketakwaan manusia kepada Allah SWT. Justeru, mereka tidak terus bersedih dan meratap. Kepercayaan kepada kekuasaan Allah SWT dan setiap apa yang berlaku dianggap sebagai ada hikmah serta takdir yang telah ditetapkan menjadikan mereka tidak terus dibelenggu emosi sedih.

\section{Gaya Bahasa}

Bahasa merupakan medium terpenting dalam penghasilan karya kreatif. Aspek bahasa atau gaya bahasa atau disebut juga stail ialah melihat bagaimana pengarang menggunakan alatnya, iaitu bahasa dalam berkarya. Sebagai bahasa yang digunakan dalam penulisan kreatif, harus memiliki unsur-unsur yang dramatik dan gayanya yang tersendiri. Ini bersesuaian dengan pendapat Mana Sikana (2012) bahawa kesempurnaan bahasa dalam sesebuah karya sastera bergantung kepada bagaimana penulis mengetengahkannya. Antaranya ialah melalui pemilihan perkataan, membina dan menyusun ayat, memberi makna yang tepat dan juga menggunakan unsur-unsur bahasa yang indah seperti unsur simile, metafora, kiasan, perbandingan, sterometri, aforisme dan lain-lain. Antara gaya bahasa yang dapat dikesan dalam kajian ini ialah hiperbola dan peribahasa.

Misalnya dalam novel Di Sebalik Dinara (2012), pengarangnya Dayang Noor memilih gaya bahasa hiperbola dalam menggambarkan sesuatu peristiwa. Hiperbola ialah gaya bahasa yang digunakan untuk membuat perbandingan yang berlebihan atau melampau. Dalam konteks kajian ini, penggunaan gaya bahasa hiperbola berperanan dalam memberikan penekanan yang lebih jelas dan mendalam mengenai keadaan balai berlepas Lapangan Terbang Senai yang dipenuhi dengan 'selautan manusia'. Penekanan perkataan 'selautan' menunjukkan bahawa balai berlepas Lapangan Terbang Senai merupakan tempat yang paling sibuk dan menjadi tumpuan orang ramai. Ini dapat dilihat melalui petikan berikut: 
Farisha berjalan susup-sasap untuk melepasi selautan manusia yang memenuhi balai berlepas Lapangan Terbang Senai.

Selanjutnya dalam novel Tawanan Komander Caucasus (2010), pengarangnya Ruzaini Yahya kerap menggunakan peribahasa dalam menggambarkan sesuatu peristiwa. Secara mudah, peribahasa dapat difahami sebagai rangkaian kata yang digunakan untuk meluahkan perasaan sama ada sindiran atau pengajaran yang digunakan oleh orang tua-tua dahulu. Misalnya, peribahasa "kerana nila setitik rosak susu sebelanga" dan "kerana seekor kerbau membawa lumpur semua terpalit" dalam petikan di bawah ini membawa maksud seorang yang buat salah, orang lain turut terpalit. Dalam konteks kajian ini, kedua-dua peribahasa tersebut berfungsi menjelaskan tanggapan negatif Caucasus yang menculik Farhani kerana mendakwa semua manusia itu jahat dan ingin memusnahkan spesis kumbang. Ini dapat dibuktikan dalam petikan di bawah:

Farhani kaget. Dia takut, tetapi dia tidak mahu dituduh secara semberono. Caucausus bersikap tidak adil kepadanya. Agaknya, inilah yang dikatakan kerana nila setitik rosak susu sebelanga. Atau kerana seekor kerbau membawa lumpur semua terpalit. Peribahasa itu baru minggu lepas dipelajarinya dalam mata pelajaran Bahasa Melayu di sekolah. Cikgu Mazlan memang sering memberikan contoh-contoh peribahasa yang dapat digunakan dalam kehidupan seharian.

(Tawanan Komander Caucasus, 2010:36)

Sehubungan dengan itu, penggunaan gaya bahasa hiperbola dan peribahasa dalam contoh petikan teks di atas menggambarkan kehalusan dan kesopanan masyarakat Melayu dalam berbahasa. Unsur-unsur alam seperti laut dan simbolik haiwan ini dapat menimbulkan kesan estetika dan menunjukkan keakraban masyarakat Melayu dengan alam. Inilah yang ditegaskan oleh Mohd Yusof Hasan (2007) sebagai Pemikiran Kekreatifan, iaitu bersifat seni, indah, cantik dan kreatif.

\section{KESIMPULAN}

Berdasarkan kajian yang telah dilakukan terhadap dua novel buah remaja iaitu Tawanan Komander Caucasus (2010) karya Ruzaini Yahya dan Di Sebalik Dinara (2012) karya Dayang Noor jelas memaparkan unsur sains dan sastera yang seimbang kepada pembaca remaja. Unsur sains yang diketengahkan dalam novel Tawanan Komander Caucasus ialah bidang sains zoologi yang mengkaji struktur atau bentuk haiwan. Dalam novel ini memerihalkan spesis kumbang seperti Coleopetra dan Lampyridae, manakala novel Di Sebalik Dinara memaparkan sains gunaan, iaitu proses pengecaman DNA seseorang pewaris. Seterusnya unsur sastera pula merangkumi aspek pemikiran, nilai murni, emosi dan gaya bahasa yang menerapkan elemen sosial yang bermakna. Menurut Husna Faredza et al (2018), sekecil-kecil penanda dalam bahasa perlu dihayati pada aras tinggi agar makna dan nilainya dapat dihayati dengan berkesan. Berdasarkan pembacaan pengkaji juga, unsur sains yang diketengahkan dalam kedua-dua novel kajian berlandaskan fakta dan dapat dibuktikan kesahihannya. Keseimbangan kedua-dua unsur sains dan sastera ini menyanggal dakwaan sesetengah pihak yang mengatakan novel remaja berunsur sains tidak memaparkan maklumat sains yang tepat serta mengabaikan nilai sastera. Penerapan teori Sistem Pemikiran Bersepadu (SPB4K) yang mempunyai empat prinsip, iaitu Pemikiran Kerohanian, Pemikiran Kebitaraan, Pemikiran Kesaintifikan dan Pemikiran Kekreatifan dapat diterap sepenuhnya dalam kajian ini. Ini jelas membuktikan bahawa novel remaja berunsur sains mempunyai keseimbangan antara hoka (sains) dan hoki (sastera). 


\section{RUJUKAN}

Al-Quran dan Terjemahannya. (1992). Hasbi Ashshiddiqi et al. Medinah: Kadim al-Harramah Department Haji dan Wakaf Saudi Arabia.

Abdul Ahmad. (Julai, 1991). "Sastera Remaja antara Ciri dan Fungsi”. Dewan Sastera, 10-13.

Ahmad Patria Abdullah. (Mac, 2009). "Penulis Muda dalam Karya Fantasi dan Futuristik". Tunas Cipta, 30-33.

Asmad. (1990). Seni Kehidupan dan Kemasyarakatan. Kuala Lumpur: Cetaktama Sdn. Bhd.

Baha Zain. (1991). Mendekati Kesusasteraan. Kuala Lumpur: Dewan Bahasa dan Pustaka.

Che Bakar Che Mat, Salmah Hussin dan Wan Ariffin Yon. 2007. Pengenalan kepada Sistem Kemasyarakatan dan Kenegaraan Islam. Shah Alam: Pusat Penerbitan Universiti, UITM.

Collins English Dictionary. (2009). Glasgow: HarperCollins.

Dayang Noor. (2012). Di Sebalik Dinara. Kuala Lumpur: Utusan Pubications \& Distributions Sdn Bhd.

Esa Khalid. (2008). Konsep Tamadun Islam: Sains dan Teknologi. Skudai: Universiti Teknologi Malaysia

Diah Aryulina, Choirul Muslim, Syalfinaf Manaf \& Endang Winarni. (2004). Biologi SMA dan MA untuk kelas X. Jakarta: Penerbit Erlangga.

Faziela Abu Bakar@ Che Din. (2016). Unsur Emosi dan Konflik dalam Novel KOMSAS Pilihan. (Tesis Master tidak diterbitkan). Universiti Putra Malaysia, Serdang.

Faziela Abu Bakar@ Che Din dan Nik Rafidah Nik Muhamad Affendi. (2015). Unsur Emosi dalam Novel KOMSAS. Pendeta: Jurnal Bahasa, Pendidikan dan Sastera Melayu 6, 72-97.

Fullick, Ann. (2010). (Terjemahan Sadatul Nazirah Abd. Hamid). Sains Forensik. Kuala Lumpur: Dewan Bahasa dan Pustaka.

Hari Purnomo. (2010). Pengantar Pengendalian Hayati. Yogjakarta: Penerbit Andi.

Hashim Awang. (Oktober, 1998). "Teori dan Kritikan Kesusasteraan Melayu”. Dewan Sastera, 7-10.

Hizairi Othman. (Mei, 1998). "Unsur Sains dan Fantasi dalam Novel Remaja”. Dewan Sastera, 24-29.

Husna Faredza Mohamed Redzwan, Anida Sarudin, Khairul Azam Bahari (2018). Upaya Berbahasa Melayu Tinggi dan Berbudaya (BMTB) dari sudut morfo-fonetik dan sosiolinguistik dalam kalangan guru pelatih. Journal of Humanities, Language, Culture \& Business Journal. 2(8), 153-161.

Iman Musbikin. (2012). Kelahiran Manusia Klon Pertama. Yogkarta: Al- Hidayah Publisher

Jumali Selamat. (2012). Sejarah Perkembangan Novel Remaja di Malaysia. Kuala Lumpur: Dewan Bahasa dan Pustaka.

Kamarul Azmi Jasmi. (2013). Bootani, Zoologi dan Tenaga dari Perspektif Al Quran.Skudai: Universti Teknologi Malaysia.

Kamariah Kamarudin. (Apr. 2017). Mau'izah remaja dalam novel Satu Bulan Tiga Bintang karya Ummu Hani Abu Hassan. Kertas Kerja dibentangkan di Persidangan Antarabangsa Sains Sosial \& Kemanusiaan Kali ke-2 (PASAK 2017), Pusat Konvensyen Kolej Universiti Islam Antarabangsa Selangor.

Kamus Oxford Edisi Kelima. (2011). Kuala Lumpur: Oxford Fajar.

Khatijah Abdul Hamid. "Perkaedahan Pengajaran Sastera: Satu Tinjuan dan Penilaian". Seminar Bahasa dalam Pendidikan ke-3. Kuala Lumpur, 7-9 April 1987.

Laurent Metzger. (2009). Nilai-nilai Melayu: Satu Sudut Pandangan Orang Luar. Tanjong Malim: Universiti Pendidikan Sultan Idris.

Maisarah Yaacob. (2017). Unsur Tarbiah dalam Novel Komsas. (Tesis Kedoktoran tidak diterbitkan). Universiti Putra Malaysia, Serdang.

Mana Sikana. (2012). Teori Sastera Kontemporari, Edisi VII. Ipoh: Pustaka Karya.

Mardzelah Makhsin. (2007). Sains Pemikiran dan Etika. Kuala Lumpur: PTS Professional.Mohd. Taib Osman. (1989). "Masyarakat, Kebudayaan dan Kesusasteraan. Dlm Ayob Yamin dan Hamzah Hamdani. Penulisan Kreatif. Kuala Lumpur: Dewan Bahasa dan Pustaka.

Mohd.Yusof Hasan. (2007). Teori Pendidikan Pemikiran Global. Penerbit Tanjong Malim Universiti Pendidikan Sultan Idris.

Mohd Yusof Hasan. (2004). Pembinaan Paradigma Pemikiran Peradaban Melayu. Tanjong Malim: Universiti Pendidikan Sultan Idris.

Mohd Yusof Hasan. (2002). Teori SPB4L dan Penerapannya. Dewan Sastera, 6-14.

Muhammad Yusuf Khalid, Syamsul Bahri Andi Galigo dan Mohd Radhi Ibrahim. (2005). Isu Dakwah dan Kemanusiaan dalam Era Globalisasi. Kuala Lumpur: Kolej Universiti Islam Malaysia.

Nor Raudhah Hj. Siren. (2006). Falsafah Diri Remaja dalam Novel Remaja Melayu. Kuala Lumpur: Dewan Bahasa dan Pustaka. 
Nurhamizah Hashim. (2015). Psikologi keperluan remaja dalam novel-novel remaja Hadiah Sastera Kumpulan Utusan (HSKU). (Tesis Kedoktoran tidak diterbitkan). Kuala Lumpur: Universiti Malaya.

Othman Puteh. (1989). Sastera Remaja Ditinjau Daripada Beberapa Perspektif. Kuala Lumpur: Dewan Bahasa dan Pustaka.

Rebecca Ilham. (2012). "Bahasa sebagai Titik Temu Sains dan Sastera”. Dewan Sastera, 13-16.

Rosnani Md Zain dan Nik Rafidah Nik Muhamad Affendi. (2019). Pemikiran dalam Pantai Kasih. Jurnal Rampak Serantau. 26 (10-15).

Rosnani Md Zain dan Nik Rafidah Nik Muhamad Affendi. (2017). Fenomena Sosial dalam Novel Nenek karya Razali Endun. Pendeta: Jurnal Bahasa, Pendidikan dan Sastera Melayu 8, 82-95.

Ruzaini Yahya. (2010). Tawanan Komander Caucasus. Kuala Lumpur: Utusan Publications and Distributions Sdn Bhd.

Sarudin, A., Mohamed Redzwan, H. F., Osman, Z., Raja Ma'amor Shah, R. N.F., \& Mohd Ariff Albkri, I. S. (2019). Menangani kekaburan kemahiran prosedurdan terminologi awal matematik: Pendekatan leksis berdasarkan teori prosodi semantik. Malaysian Journal of Learning and Insruction, 16 (2), 255-294.

S. Othman Kelantan. (1997). Pemikiran Satira dalam Novel Melayu. Kuala Lumpur: Dewan Bahasa dan Pustaka.

Sahlan Mohd Saman. (1989)." Pembinaan Sastera Remaja". Dewan Sastera, 3-5.

Seth Sulaiman. (2000). Pendidikan sains, teknologi dan masyarakat. Jurnal Pendidikan Universiti Teknologi Malaysia, 6 (1), 66-76.

Shahnon Ahmad. (1991). Sastera Sebagai Seismografi Kehiduapan. Kuala Lumpur: Dewan Bahasa dan Pustaka.

Shaharir Mohamad Zain. (1987). Pengenalan Tamadun Islam dalam Sains dan Teknologi. Kuala Lumpur: Dewan Bahasa dan Pustaka.

Siti Khariah Mohd Zubir. (2008). Citra Wanita Dalam Novel Melayu. Tanjong Malim: Universiti Pendidikan Sultan Idris.

Siti Khariah Mohd Zubir. (2011). "Penulisan Kreatif dalam Menjana Minda dan Sumber Pendapatan Belia". Malaysian Journal of Youth Studies, 4, 157-167.

Tengku Sifzizul Tengku Muhammad dan Ahmad Sofiman Othman. (2004). Penanda DNA untuk Kepelbagaian Genetik. Pulau Pinang: Penerbit Universiti Sains Malaysia.

Yaacob Harun. (1991). Keluarga Melayu Bandar: Satu Analisis Perubahan. Kuala Lumpur: Dewan Bahasa dan Pustaka. 